The Long-Range Atmospheric Transport of Natural and Contaminant Substances 


\section{The Long-Range Atmospheric Transport of Natural and Contaminant Substances}

edited by

\section{Anthony H. Knap}

Bermuda Biological Station for Research,

Inc., Ferry Reach, Bermuda

and

Mary-Scott Kaiser

Technical Editor

\section{Kluwer Academic Publishers}

Dordrecht / Boston / London

Published in cooperation with NATO Scientific Affairs Division 
Proceedings of the NATO Advanced Research Workshop on

The Long-Range Atmospheric Transport of Natural and Contaminant

Substances from Continent to Ocean and Continent to Continent

St. Georges, Bermuda

January 10-17, 1988

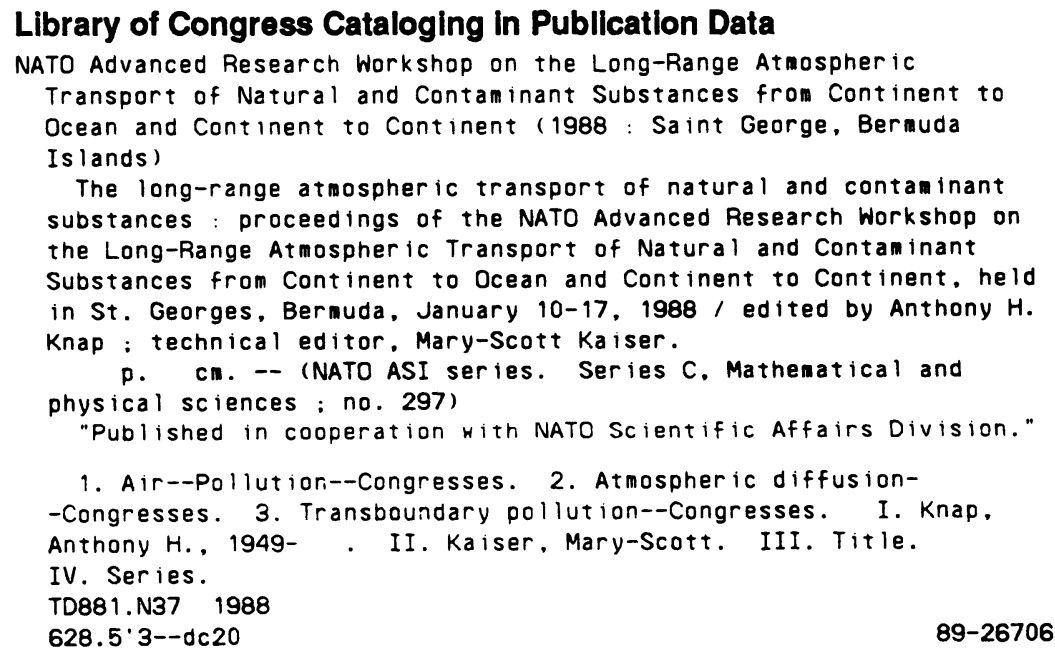

Published by Kluwer Academic Publishers,

P.O. Box 17, 3300 AA Dordrecht, The Netherlands.

Kluwer Academic Publishers incorporates the publishing programmes of

D. Reidel, Martinus Nijhoff, Dr W. Junk and MTP Press.

Sold and distributed in the U.S.A. and Canada

by Kluwer Academic Publishers,

101 Philip Drive, Norwell, MA 02061, U.S.A.

In all other countries, sold and distributed

by Kluwer Academic Publishers Group,

P.O. Box 322, 3300 AH Dordrecht, The Netherlands.

\section{Printed on acid-free paper}

All Rights Reserved

(C) 1990 by Kluwer Academic Publishers

Softcover reprint of the hardcover 1st edition 1990

No part of the material protected by this copyright notice may be reproduced or utilized in any form or by any means, electronic or mechanical, including photocopying, recording or by any information storage and retrieval system, without written permission from the copyright owner. 
This book contains the proceedings of a NATO Advanced Research Workshop held within the programme of activities of the NATO Special Programme on Global Transport Mechanisms in the Geo-Sciences running from 1983 to 1988 as part of the activities of the NATO Science Committee.

Other books previously published as a result of the activities of the Special Programme are:

BUAT-MENARD, P. (Ed.) - The Role of Air-Sea Exchange in Geochemical Cycling (C185) 1986

CAZENAVE, A. (Ed.) - Earth Rotation: Solved and Unsolved Problems (C187) 1986

WILLEBRAND, J. and ANDERSON, D.L.T. (Eds.) - Large-Scale Transport Processes in Oceans and Atmosphere (C190) 1986

NICOLIS, C. and NICOLIS, G. (Eds.) - Irreversible Phenomena and Dynamical Systems Analysis in Geosciences (C192) 1986

PARSONS, I. (Ed.) - Origins of Igneous Layering (C196) 1987

LOPER, E. (Ed.) - Structure and Dynamics of Partially Solidified Systems (E125) 1987

VAUGHAN, R. A. (Ed.) - Remote Sensing Applications in Meteorology and Climatology (C201) 1987

BERGER, W. H. and LABEYRIE, L. D. (Eds.) - Abrupt Climatic Change - Evidence and Implications (C216) 1987

VISCONTI, G. and GARCIA, R. (Eds.) - Transport Processes in the Middle Atmosphere (C213) 1987

SIMMERS, I. (Ed.) - Estimation of Natural Recharge of Groundwater (C222) 1987

HELGESON, H. C. (Ed.) - Chemical Transport in Metasomatic Processes (C218) 1987

CUSTODIO, E., GURGUI, A. and LOBO FERREIRA, J. P. (Eds.) - Groundwater Flow and Quality Modelling (C224) 1987

ISAKSEN, I. S. A. (Ed.) - Tropospheric Ozone (C227) 1988

SCHLESINGER, M.E. (Ed.) - Physically-Based Modelling and Simulation of Climate and Climatic Change 2 vols. (C243) 1988

UNSWORTH, M. H. and FOWLER, D. (Eds.) - Acid Deposition at High Elevation Sites (C252) 1988

KISSEL, C. and LAY, C. (Eds.) - Paleomagnetic Rotations and Continental Deformation (C254) 1988

HART, S. R. and GULEN, L. (Eds.) - Crust/Mantle Recycling at Subduction Zones (C258) 1989

GREGERSEN, S. and BASHAM, P. (Eds.) - Earthquakes at North-Atlantic Passive Margins: Neotectonics and Postglacial Rebound (C266) 1989

MOREL-SEYTOUX, H. J. (Ed.) - Unsaturated Flow in Hydrologic Modeling (C275) 1989

BRIDGWATER, D. (Ed.) - Fluid Movements - Element Transport and the Composition of the Crust (C281) 1989

LEINEN, M. and SARNTHEIN, M. (Eds.) - Paleoclimatology and Paleometeorology: Modern and Past Patterns of Global Atmospheric Transport (C282) 1989

ANDERSON, D.L.T. and WILLEBRAND, J. (Eds.) - Ocean Circulation Models: Combining Data and Dynamics (C284) 1989

BERGER, A., SCHNEIDER, S. and DUPLESSY, J. Cl. (Eds.) - Climate and Geo-Sciences (C285) 1989 


\section{TABLE OF COMENTS}

Participants

List of Figures

List of Tables.

Preface

Abstract

Intoduction

Chapter 1. LARGE-SCALE METEOROLOGICAL REGIMES AND TRANSPORT

PROCESSES: D. M. Whelpdale and J. L. Moody . . . . 3

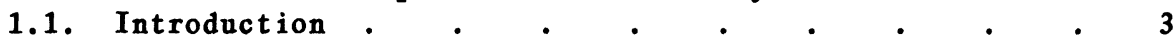

1.2. Long-range-Transport 0verview $\quad$. $\quad . \quad . \quad . \quad . \quad 4$

1.3. The Atmospheric Pathway . . . . . . . . 21

1.4. Concluding Remarks. . . . . . . . . . 32

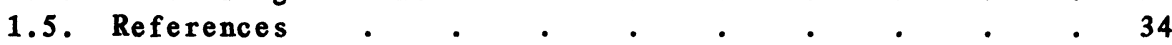

Chapter 2. THE LONG-RANGE ATMOSPHERIC TRANSPORT OF TRACE ELEMENTS

A CRITICal Evaluation: T. M. Church, R. Arimoto, L. A. Barrie,

F. Dehairs, F. Dulac, T. D. Jicke11s, L. Mart, W. T. Sturges,

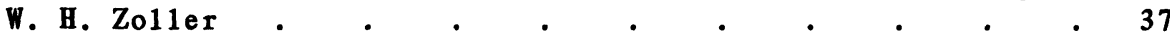

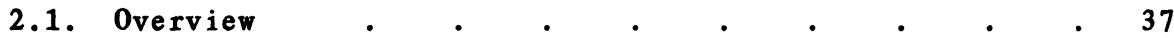

2.2. Atmospheric Trace Elements and Their Sources . . 38

2.3. Trace-element Emissions to the Atmosphere . . . 46

2.4. Atmospheric Trace-element Transport . . . . . 47

2.5. Atmospheric Trace-element Scavenging . . . . 48

\begin{tabular}{c} 
2.6. Trace-element Recycling Between the Atmosphere \\
and 0ceans . \\
\hline
\end{tabular}

2.7. Trace-element Deposition . . . . . . . 50

2.8. The Effects and Significance. $. \quad . \quad . \quad . \quad . \quad 50$

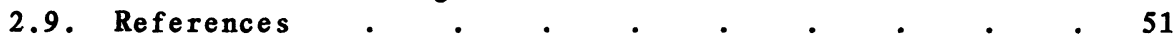

Chapter 3. MINERAL-AEROSOL TRANSPORT TO THE NORTH ATLANTIC AND

NORTH PACIFIC: THE IMPACT OF AFRICAN AND ASIAN SOURCES:

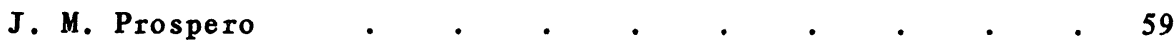

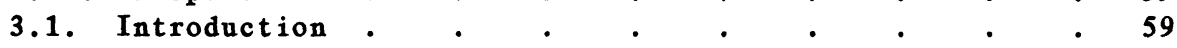

3.2. African Dust Transport Across the Tropical

3.3. Transport of Asian Dust Across the North Pacific . $\quad 74$

3.4. Discussion and Conclusions . $\quad . \quad$. $\quad . \quad$. $\quad$. 81

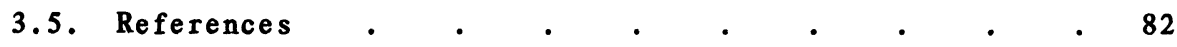

Chapter 4. THE INTERCONTINENTAL TRANSPORT OF SULFUR AND NITROGEN:

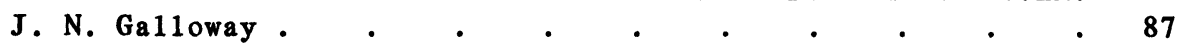

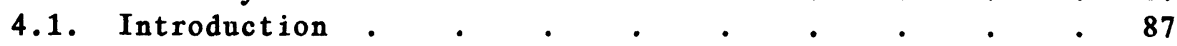

4.2. Sulfur and Nitrogen Characteristics . $\quad . \quad$. $\quad .87$

4.3. The Long-range Transport of Sulfur and Nitrogen . . 91

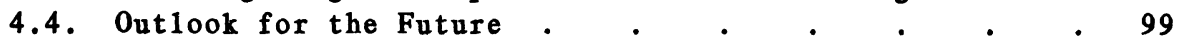

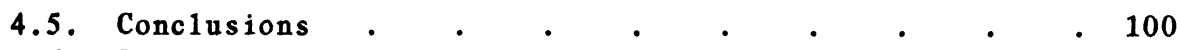

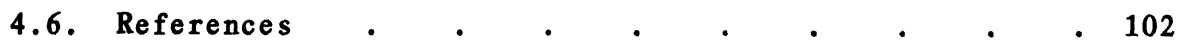


viii

Chapter 5. THE LONG-RANGE TRANSPORT OF ORGANIC COMPOUNDS:

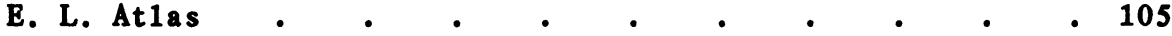

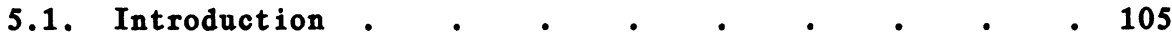

5.2. Analytical Aspects . $\quad . \quad$. $\quad . \quad . \quad . \quad .106$

5.3. Concentration Distribution . . . . . . . 106

5.4. Rates of Atmospheric Deposition . . . . . . 118

5.5. Transformations . . . . . . . . 123

5.6. References $. \quad . \quad . \quad . \quad . \quad . \quad . \quad . \quad .128$

Chapter 6. ARCTIC AIR POLLUTION: A CASE STUDY OF CONTINENT-TO-

OCEAN-TO-CONTINENT TRANSPORT: L. A. Barrie . . . $\quad$. 137

6.1. The Phenomenon of Arctic Air Pollution . . . . 137

6.2. Sulfur Transport into the Arctic . . . . . 143

6.3. Knowledge Gaps and Future Research . . . . 147

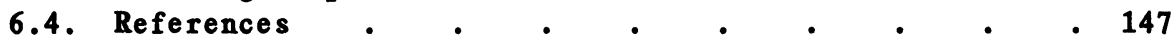

Chapter 7. CHERNOBYL: A SUMMARY CASE STUDY WITH EMPHASIS ON

THE TRANSPORT AND DEPOSITION TO SCANDINAVIA:

A. E1 iassen

7.1. Conclusions

7.2. References

Chapter 8. GLOBAL SOURCE STRENGTH AND LARGE-RANGE ATMOSPHERIC

TRANSPORT OF TRACE ELEMENTS EMITTED BY VOLCANIC ACTIVITY :

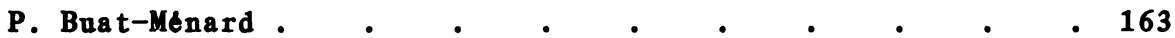

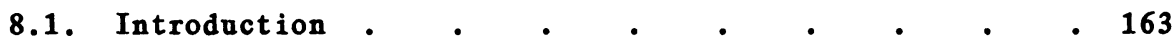

8.2. The Effect of Volcanoes on the Atmospheric Sulfur 164

8.3. The Volcanic Sulfur Fal1-out in Polar Snow and Ice .165

8.4. Volcanic Output of Trace Elements into the Atmosphere . 168

8.5. $210 \mathrm{Po} / 210 \mathrm{~Pb}$ as a Tracer of the Long-range Transport of Volcanic Aerosols $\quad . \quad$. $\quad . \quad . \quad . \quad . \quad .172$

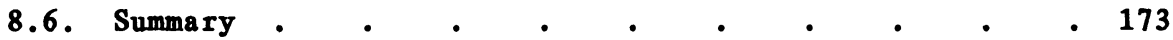

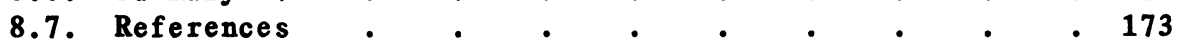

Chapter 9: THE LONG-RANGE TRANSPORT OF TRACE ELEMENTS: FOUR CASE

STUDIES: T. D. Jicke11s, R. Arimoto, L. A. Barrie,

T. M. Church, F. Dehairs, F. Dulac, L. Mart, W. T. Sturges,

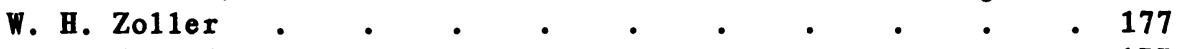

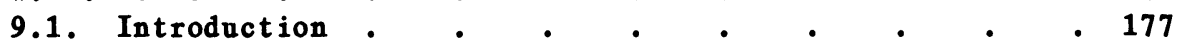

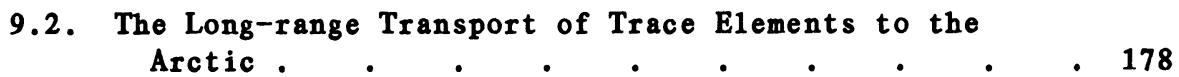

9.3. The Long-range Transport of Trace Elements to the
Pacific Ocean $. \quad . \quad . \quad . \quad . \quad . \quad . \quad 180$

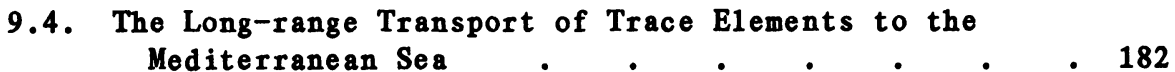

9.5. The Transport of Trace Elements Across the North

Atlantic Ocean $\quad . \quad . \quad . \quad . \quad . \quad . \quad . \quad .184$ 
Chapter 9: Trace Elements - continued

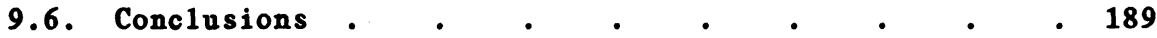

9.7. Recommendations . $\quad . \quad$. $\quad . \quad$. $\quad . \quad . \quad .190$

9.8. References $. \quad . \quad . \quad . \quad . \quad . \quad . \quad . \quad . \quad . \quad . \quad 191$

Chapter 10: THE LONG-RANGE TRANSPORT OF MINERAL AEROSOLS: GROUP REPORT:

L. W. Schutz, J. M. Prospero, P. Buat-Menard, R. A. C. Carva1ho,

A. Cruzado, R. Harriss, N. Z. Heidam, R. Jaenicke . . . 197

10.1. Introduction . . . . . . . . . . 197

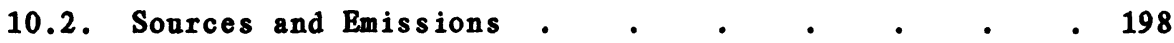

10.3. Transport and Transformation . . . . . 204

10.4. Deposition . . . . . . . . . . . 213

10.5. The Significance and Impact of the Long-Range

10.6. Conclusions and Recommendations . . . . . . 220

10.7. References . . . . . . . . . . $\quad$. 223

Chapter 11: THE LONG-RANGE TRANSPORT OF SULFUR AND NITROGEN COMPOUNDS:

H. Levy, II, A. Eliassen, B. E. A. Fisher, J. N. Galloway,

R. Gorze1ska, D. R. Hastie, J. L. Moody, A. G. Ryaboshapko,

D. L. Savoie, D. M. Whelpdale . . . . . . . 231

11.1. Introduction . $\quad . \quad$. $\quad . \quad$. $\quad . \quad$. 231

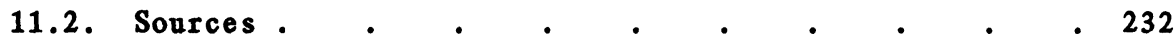

11.3. Favorable Transport Conditions . . . . . $\quad$. 233

11.4. Vertical Transport . . . . . . . . 233

11.5. Chemical Transformations . . . . . . . 234

11.6. Deposition Processes . $\quad . \quad$. $\quad . \quad . \quad . \quad .235$

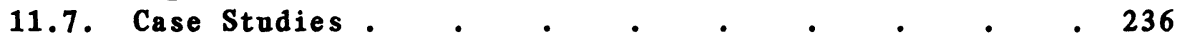

11.8. Uncertainties, Gaps, and Recommendations . . . 251

11.9. References . $\quad . \quad$. $\quad . \quad . \quad . \quad . \quad . \quad . \quad 254$

Chapter 12: THE LONG-RANGE TRANSPORT OF ORGANIC COMPOUNDS:

T. Bidleman, E. L. Atlas, R. Atkinson, B. Bonsang, K. Burns,

W. C. Keene, A, H. Knap, J. Miller, J. Rudolph, S. Tanabe . 259

12.1. Introduction. . . . . . . . . . 259

12.2. Significance and Rationale $. \quad . \quad . \quad . \quad . \quad . \quad$. 260

12.3. Sources. $. \quad . \quad . \quad . \quad . \quad . \quad . \quad . \quad .262$

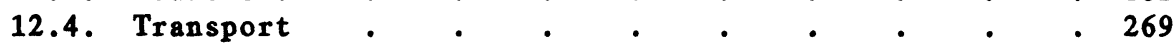

12.5. Deposition . . . . . . . . . . 275

12.6. Transformations . $\quad . \quad$. $\quad . \quad$. $\quad . \quad . \quad .280$

12.7. Recommendations . . . . . . . . . . $\quad . \quad$. 287

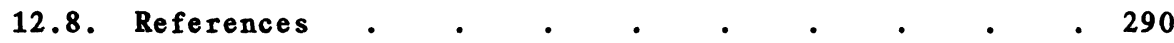

Chapter 13: CONCLUSIONS: A. H. Knap . . . . . . 303

13.1. Introduction . . . . . . . . . . 303

13.2. Trace Elements . . . . . . . . . 303

13.3. Mineral Aerosols . . . . . . . . . . 303

13.4. Sulfur and Nitrogen . . . . . . . . 304

13.5. Organic Compounds . . . . . . . . . . 305 
Chapter 14: GAPS AND FUTURE RESEARCH RECOMMENDATIONS:
A. H. Knap
14.1. Gaps
14.2. Recommendations for Future Research
307
307

Appendix

311

Index 
Richard Arinoto

Roger Atkinson

B11 iot L. Atlas

Leonard A. Barrie

Terry Bidleann

Bernard Bonsang

Patrick Buat-Monard

Katheryn Burns

Renato A. C. Carvalho

Thonas H. Church

Antonio Cruzado

Frank Dehairs

Jan Duinker

Francois Dulac

Manfred Bhrhardt

Anton B1iassen

Bernard B. A. Fisher

James N. Galloway

Krystyna Gorzelska

Robert Harriss
Donald R. Hastie

Neils Z. Heidan

Ruprecht Jaenicke

Tinothy D. Jicke11s

Villian C. Keene

Anthong H. Inap

Hiran Levy, II

Leon Mart

John Mil1er

Jennie L. Moody

Joseph M. Prospero

Jochen Rudolph

Alerey G. Ryaboshapko

Dennis L. Savoie

Lothar Schutz

Villian T. Sturges

Shinsuke Tanabe

Douglas $M$. Whelpdale

villian H. Zo11er

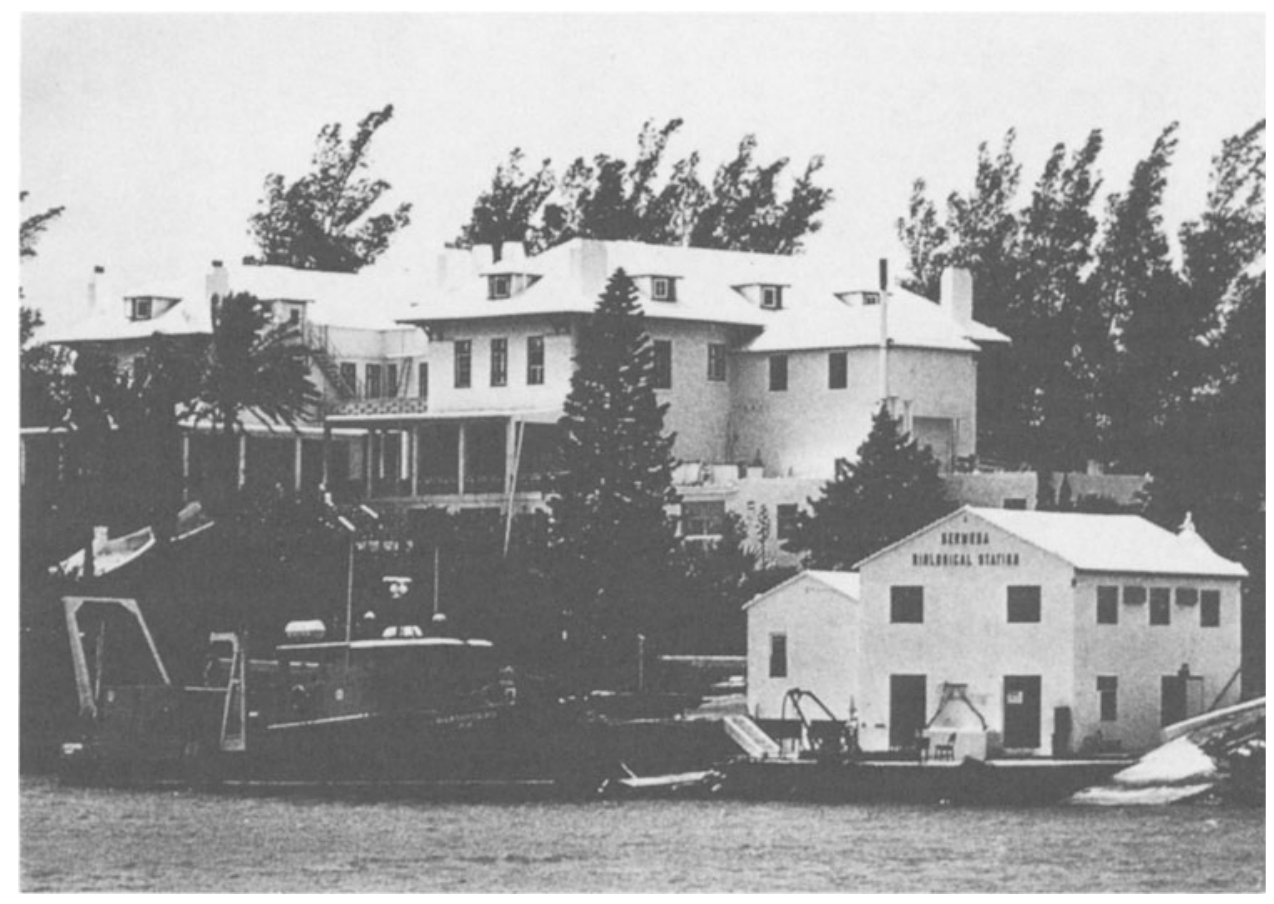




\section{LIST OF FIGURES}

1-1. North Atlantic mean sea-1eve1 pressures and winds (January)

1-3. North Atlantic mean sea-1evel pressures and winds $(\mathrm{Ju} 1 \mathrm{y})$

1-4. July storm tracks across North At1antic

1-5. Resultant January and July 500-mb streamlines . . . 9

1-6. South Atlantic mean sea-1eve1 pressures and winds

(January) $\quad . \quad . \quad . \quad . \quad . \quad . \quad . \quad . \quad .10$

1-7. South Atlantic mean sea-1eve1 pressures and winds
$(\mathrm{Ju} 1 \mathrm{y})$

1-8. Daily cyclone center positions and tracks for February and August, $1963 \quad$. $\quad . \quad \ldots \quad . \quad . \quad . \quad . \quad . \quad . \quad . \quad 12$

1-9. North Pacific mean sea-level pressures and winds

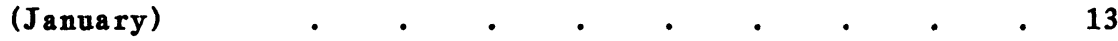

1-10. North Pacific mean sea-level pressures and winds

1-11. Frequency of wind directions over North Pacific $\quad . \quad 15$

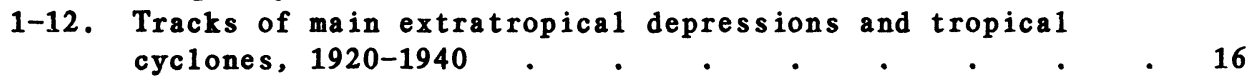

\begin{tabular}{l} 
1-13. South Pacific mean surface vector winds, January \\
and July \\
\hline
\end{tabular}

\begin{tabular}{l} 
1-14. South Pacific mean sea-1eve1 pressures and winds \\
(January) \\
\hline
\end{tabular}

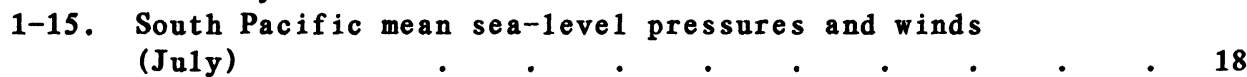

1-16. Coarse, volcanic glass on ocean floor $\quad . \quad$. $\quad . \quad$. 20

1-17. Atmospheric pathway between source and receptor . $\quad 22$

3-1. Month1y mean trade-wind minera1-aerosol concentrations, Barbados, 1965-1984 . . . . . . . . . 63

3-2. Daily dust concentrations at Barbados . . . . 64

3-3. Daily concentrations of mineral aeroso1, nss-sulfate, and nitrate at Barbados, 1985 . $\quad . \quad . \quad . \quad . \quad .68$

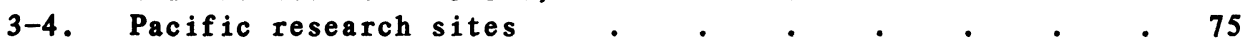

3-5. Mineral dust in onshore winds, Midway Island . . . 75

3-6. Minera1-aerosol frequency distributions, Pacific . . 77

4-1. Chemical transformation of sulfur in the atmosphere. . 88

4-2. Chemical transformation of nitrogen in the atmosphere $\quad 92$

4-3. Estimated 1980 sulfur emissions to the atmosphere . . 94

4-4. Estimated sulfur and nitrogen-oxide advection rates from North America . . . . . . . . . 95

4-5. Population distribution in China $. \quad . \quad . \quad . \quad . \quad 97$

4-6. World-population figures, 1980 and 2020 . . . 100

4-7. Worldwide sulfur and nitrogen-oxide emissions, 1980 and
2020
. 
5-1. Hydrocarbons and perchloretylene in Atlantic atmosphere $\quad 108$

5-2. Marine particulate carbon isotopic composition as function of concentration . . . . . . . . . . 118

5-3. Estimated air-sea fluxes in North Pacific, PCB(1254) and a-HCH $\quad . \quad . \quad . \quad . \quad . \quad . \quad . \quad . \quad .121$

5-4. Measured versus predicted concentrations at Enewetak . 122

5-5. Atmospheric gaseous organic 1ifetimes . . . . $\quad . \quad 124$

5-6. Temporal and covariations of radon and alkyl nitrates . 126

5-7. Present knowledge of long-range transport . . . . 128

6-1. Temporal variations of sulfur in Canadian Arctic . . 138

6-2. Seasonal variations in precipitation in Canadian Arctic . 139

6-3. Atmospheric temporal variations in Canadian Arctic . . 139

6-4. Estimated mean vertical profile of anthropogenic aerosol mass in Canadian high Arctic . . . . $\quad 140$

6-5. Three main sources of air for North American airshed and spatial distribution of arithmetic mean atmospheric $\mathrm{SO}_{4}=141$

6-6. Historical record of $\mathrm{SO}_{4}=$ and $\mathrm{NO}_{3}{ }^{-}$from Greenland ice 142

6-7. Historical records of conductivity in Agassiz glacier versus European $\mathrm{SO}_{2}$ emissions . . . . . . . 142

6-8. Sulfur emission to the Arctic circle . . . . . . 144

6-9. Observed atmospheric $\mathrm{SO}_{4}=$ and $\mathrm{SO}_{2}$ versus model calculations $\quad . \quad . \quad . \quad . \quad . \quad . \quad . \quad . \quad . \quad 145$

6-10. Sulfur flux into Arctic atmosphere as function of source 146

6-11. Temporal various of monthly sulfur flux to Arctic . . 146

7-1. Daily radioactive releases from Chernoby1 . . . . 150

7-2. Surface weather maps, Apri1 25-28, 1986 ....$\quad 151$

7-3. Trajectories from Chernoby1, April $26 \quad$. $\quad . \quad . \quad$. 152

7-4. Trajectories from Chernoby1, April 27 . $\quad . \quad$. 152

7-5. Trajectories from Chernobyl, Apri1 25-30 . . . . . 153

7-6. Trajectories from Chernobyl, April 26-May 4 . . . 153

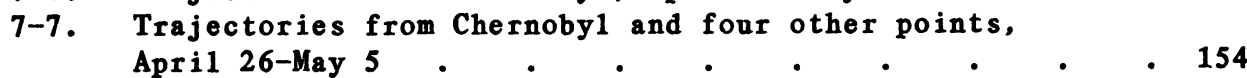

7-8. Trajectories from Chernobyl and four other points,

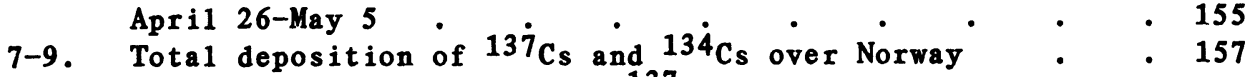

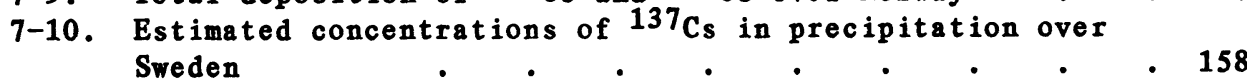

7-11. Day-by-day out1ine of Chernobyl plume, April 28-May 3 . 159

7-12. Estimated deposition of ${ }^{137} \mathrm{Cs}$ over United Kingdom . $\quad 160$

7-13. Chernobyl plume across Northern Hemisphere . . . 161

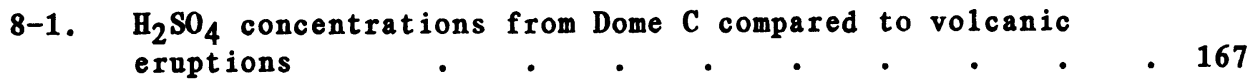

9-1. Atmospheric lead budgets over Atlantic and Arctic Oceans . 188 
10-1. Arid regions and minera1-aerosol transport directions 198

10-2. Cumulative mass distributions for Saharan soils . 199

10-3. Principal synoptic meteorological conditions for dust events and main trajectories for transport . . $\quad 202$

10-4. Transport and deposition of Saharan dust . . . . 206

10-5. Sand fractionation process by wind . . . . $\quad . \quad 208$

10-6. Enrichment factors for soils as function of particle

10-7. Dust cloud moving across tropicai North Atiantic $\cdot{ }^{-} \cdot{ }^{-} 212$

11-1. Nitrate and non-sea-salt-sulfate seasonal cycles at

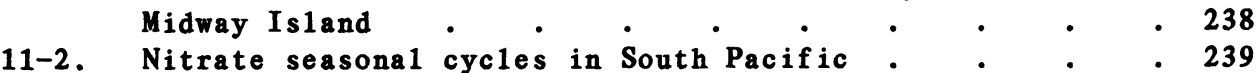

11-3. Precipitation ranked by increasing deposition, Amsterdam Island, Bermuda . $• . \quad . \quad . \quad . \quad . \quad . \quad$. 242

11-4. Precipitation ranked by increasing deposition, Amsterdam Is1and, Bermuda, Ireland . . . . . . . 242

11-5. Precipitation ranked by increasing deposition, Amsterdam Is1 and, Ireland . . . . . . . . . 243

11-6. Precipitation ranked by increasing deposition, Amsterdam Is1 and, Ire1 and, Bermuda . . . . . . . 243

11-7. North Atlantic seasonal variations of radon-222, particulate nss-sulfate, and particulate nitrate . . 247

11-8. Particulate nss-sulfate, particulate nitrate, and 248

11-9. $\mathrm{SO}_{2}$ over North Atlantic . . . . . . . . . 249

11-10. $\mathrm{NO}_{2}$ over North Atlantic $\quad . \quad+\quad . \quad+\quad . \quad+\quad . \quad+250$

12-1. Atmospheric nonmethane hydrocarbons over Amsterdam Island 270

12-2. Tropospheric DDT since $1975 \quad$. $\quad . \quad . \quad . \quad . \quad . \quad 273$ 


\section{LIST OP TABLES}

2-1. Primary sources of atmospheric tracers and trace elements

. $\quad . \quad . \quad . \quad 40$

2-2. Crustal enrichment factors. $. \quad . \quad . \quad . \quad . \quad .43$

2-3. Seawater enrichment factors . $\quad . \quad$. $\quad . \quad . \quad . \quad 44$

2-4. Atmospheric emissions of enriched trace elements . . 46

3-1. Minera1-aerosol and deposition to Tropical North

Atlantic . . . . . . . . . . 72

3-2. Mineral dust mean concentrations and distance from Asia . 76

4-1. Atmospheric sulfur compounds . . . . . . $\quad . \quad 90$

4-2. Sulfur residence $t$ imes in marine atmosphere . . . 90

4-3. Nitrogen compounds in the remote atmosphere . . . 91

5-1. Abundant organic species in Atlantic air . . . 107

5-2. Average hydrocarbon concentrations in urban U. S. . 109

5-3. $C_{2}-C_{6}$ hydrocarbons in nonurban troposphere $. \quad . \quad . \quad 110$

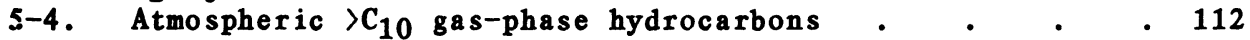

5-5. Gas-phase versus particulate PAHs in marine atmosphere . 114

5-6. Atmospheric organic compounds . . . . . $\quad . \quad 115$

5-7. Remote marine particulate carbons in aerosols . . . 117

5-8. Source marker information . $. \quad . \quad . \quad . \quad . \quad . \quad 119$

5-9. Organic air-sea fluxes in North Pacific . . . $\quad$. 120

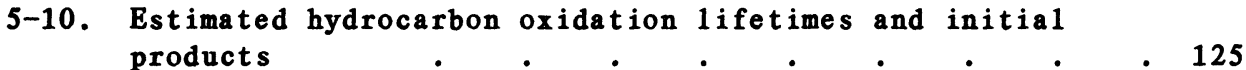

6-1. Annual $\mathrm{SO}_{2}$ emissions affecting Arctic $\quad . \quad \ldots \quad . \quad$. 147

7-1. Estimated radionuc1ide releases from Chernoby 1 . 149

8-1. Volcanic activity classes and $\mathrm{SO}_{2}$ emissions . . . 164

8-2. Element-to-sulfur weight ratios for volcanic plumes . . 169

8-3. Global volcanic metal emissions . . . . . 171

9-1. Anthropogenic trace elements to the Arctic . . . 179

9-2. Aerosol trace-element data from Delaware. . . . 185

9-3. Estimated trace-element export from North America . . 185

11-1. Remova1-process effectiveness by region and season . . 235

11-2. Remova1-process effectiveness for sulfur and nitrogen . 236

11-3. Non-sea-salt $\mathrm{SO}_{4}=$, Ireland, Bermuda,

Amsterdam Is1and . . . . . . . . . 241

11-4. Mode1-versus-observed nitrogen in wet deposition . . 245

11-5. Mode1-versus-observed surface $R\left(\mathrm{NO}_{\mathrm{y}}\right) / \mathrm{yr}$ from Pacific 245

12-1. Anthropogenic benzo(a pyrene emissions from U.S. . . 266

12-2. Worldwide chlorinated-hydrocarbon insecticide usage . . 267

12-3. Room-temperature rate constants for gas-phase reactions of OH radical with organic compounds (with lifetimes) . . 281 
We have been increasingly aware of the role of long-range atmospheric transport in the transfer of man-made and natural substances around the globe. The nuclear accident at Chernoby 1 highlighted the fact that one nation's atmospheric emissions may profoundly affect its neighbor. Over the past few years, we have gained insight into the processes governing long-range atmospheric transport. Many international and interdisciplinary research groups are already working to unravel the many problems in this field and several new global research programs have just begun (such as, the Joint Global Ocean F1ux Study [JGOFS], the World Ocean Circulation Experiment [WOCE], and the Internationa1 Geosphere/Biosphere Program [IGBP]). It was, therefore, timely to organize a workshop where-in those presently working in the field could assess the present knowledge in the field of long-range transport, identify the gaps in our knowledge, and make recommendations for future research.

The NATO Advanced Research Workshop, 'The Long-Range Atmospheric Transport of Natural and Contaminant Substances from Continent to Ocean and Continent to Continent," ' was held at the Bermuda Biological Station for Research, Inc., in St. Georges, Bermuda, from 10-17 January 1988. Thirty-nine scientists best known for their work in the field attended the workshop. This volume contains the background papers, case studies, and findings of this group of world-reknown scientists. The workshop was organized along the lines of the successful NATO ARV entitled "The Biogeochemical Cycling of Sulfur and Nitrogen in the Remote Atmosphere'. that was held at the Bermuda Biological Station in 1984.

Scientists worked in groups according to compound classes of acids, trace elements, organics, and mineral aerosols. Each group was charged with assessing the present knowledge about emissions, transport, transformation, and deposition; the aim was to focus on long-range transport (i.e., transport over $1,000 \mathrm{~km}$ ). Approximately three months before the workshop, a background paper written by the chairman of each working group was sent to each participant. At the workshop, background papers were presented on the atmospheric processes that govern large-scale transport; case histories were also presented. Fonr synthesis chapters containing the summaries of each subgroup's deliberations and consensus, a concluding chapter, and a chapter on the gaps and recommended research have been added to these papers to complete this volume.

This book should be of interest to those scientists who wish to understand some of the complexities of long-range transport and to those who wish to gain an overall assessment of our present knowledge of the problems involved. Individuals or agencies concerned with the scientific and political policy of how one country's emissions can affect another country should also be interested in reading this publication.

The main support for our workshop was supplied by the Scientific Affairs Division of the North Atlantic Treaty Organization with supplemental funding from the $U$. S. National Oceanic and Atmospheric Administration, the EXXON Corporation, the Bermuda Biological Station for 
Research, Inc., the Bermuda Government, and the W. Alton Jones Foundation.

As director of this workshop, I sincerely thank the Organizing Committee--E. L. Atlas, T. M. Church, J. N. Galloway, J. M. Prospero, and D. M. Whelpdale--for its hard work and diligence. We greatly appreciated all the help provided by the staff of the Bermuda Biological Station for Research, Inc., as well as by Brenda Morris and Louise Cruden; their attention and industry enabled our week to be especially productive. My thanks to our illustrator, Barbara Wallace, for her major effort. The Organizing Committee and $I$ also thank Mary-Scott Kaiser for her organizational help and for keeping everything and everyone straight as well as for her efforts as the technical editor of this book. I am most indebted to J. E. B. for continual support during this project. One 1 ast point: The weather played as incredible a role this time as it did for the previous NATO ARW meeting in 1984. It was so stormy that there was no choice but to meet and write--no one got a Bermuda tan!!

Anthony H. Knap

Ferry Reach, Bermuda 


\section{ABSTRACT}

Thirty-nine experts in the fields of long-range transport and meteorology agreed to participate actively in a workshop on the long-range atmospheric transport of natural and contaminant substances from continent to ocean and continent to continent. The four major compound classes addressed were trace metals, trace organics, nitrogen and sulfur compounds, and mineral aerosol. After an in-depth briefing covering the meteorological considerations required for an understanding of the longrange atmospheric transport, the state of knowledge concerning the emission, transport, transformation, and deposition of each compound was extensively discussed. Each participant was asked to bring his or her own data to the workshop. These data were discussed in the individual group meetings before being incorporated into the group-discussion chapters--sometimes as case histories, others as a general overview of the field. Gaps in our present knowledge and directions for future research were agreed to in the plenary sessions. A synthesis of the "'state of the art'" at the time was produced at the end of the workshop. 